\title{
Influence of expiration date on detail reproduction of dental elastomers
}

\author{
Influência da data de validade na reprodução de detalhes de elastômeros odontológicos \\ Influencia de la fecha de caducidad en la reproducción de detalles de los elastómeros odontológicos
}

Received: 07/28/2021 | Reviewed: 08/08/2021 | Accept: 08/30/2021 | Published: 09/02/2021

\author{
Ricardo Danil Guiraldo \\ ORCID: https://orcid.org/0000-0002-1625-3120 \\ Universidade Pitágoras Unopar, Brazil \\ E-mail: rdguiraldo@gmail.com \\ Eric Yudi Harada \\ ORCID: https://orcid.org/0000-0003-0851-6768 \\ Universidade Estadual de Londrina, Brazil \\ E-mail: eric.yudi.harada@uel.br \\ Sandrine Bittencourt Berger \\ ORCID: https://orcid.org/0000-0002-7915-3207 \\ Universidade Pitágoras Unopar, Brazil \\ E-mail: berger.sandrine@gmail.com \\ Flaviana Alves Dias \\ ORCID: https://orcid.org/0000-0003-4709-6866 \\ Universidade Pitágoras Unopar, Brazil \\ E-mail: flavi_dias@hotmail.com \\ Danielle Gregorio \\ ORCID: https://orcid.org/0000-0002-0098-624X \\ Universidade Pitágoras Unopar, Brazil \\ E-mail: daanigregorio@ hotmail.com \\ Lucia Gloria Diana Aguilar Pizzurno \\ ORCID: https://orcid.org/0000-0002-9737-4249 \\ Universidade Pitágoras Unopar, Brazil \\ E-mail: dianita.982@hotmail.com \\ Nayra Kawana Turini \\ ORCID: https://orcid.org/0000-0001-6482-3565 \\ Universidade Pitágoras Unopar, Brazil \\ E-mail: nayraturini@hotmail.com \\ Murilo Baena Lopes \\ ORCID: https://orcid.org/0000-0001-6198-7695 \\ Universidade Pitágoras Unopar, Brazil \\ E-mail: baenalopes@gmail.com
}

\begin{abstract}
Elastomers are synthetic rubber materials formed by polymers, which are joined by a small number of cross-links that form a three-dimensional network. The aim of the current study was to compare the surface detail reproduction of polyvinyl siloxane and polyether-based elastomeric impression materials ( 2 years after their expiration date) to the ones that have not exceeded this period-of-time. Four groups comprising 5 samples, each $(\mathrm{n}=5)$, were divided based on material (polyvinyl siloxane - Express and polyether - Impregum Soft) and expiration date (expired, or not). The manipulated material was placed on a tray in a way to fully cover its inner part. Later on, it was placed on a metal matrix presenting 20-, 50- and 75- $\mu \mathrm{m}$ lines. Molds were removed after polymerization and surface detail reproduction was measured in comparator microscope (Stereozoom Microscope), along the $20 \mu \mathrm{m}$ line $(25 \mathrm{~mm}$ in length), at 4x-magnification, in compliance with ISO 4823. Surface detail reproduction values were subjected to descriptive analysis - results were expressed in percentage (\%). All groups presented 100\% of surface detail reproduction, regardless of impression material or expiration date. Surface detail reproduction of the investigated materials was not influenced by the evaluated elastomers' expiration date.
\end{abstract}

Keywords: Elastomers; Dental impression materials; Date of validity of products.

\section{Resumo}

Elastômeros são materiais de borracha sintética formados por polímeros, unidos por um pequeno número de ligações cruzadas que formam uma rede tridimensional. O objetivo do presente estudo foi comparar a reprodução de detalhes da superfície dos materiais de impressão elastoméricos à base de silicona reação por adição e poliéter (2 anos após vencimento da sua data de validade) com aqueles que não ultrapassaram a validade. Quatro grupos compostos por 5 amostras, cada $(n=5)$, foram divididos com base no material (silicona reação por adição - Express e poliéter Impregum Soft) e prazo de validade (vencido ou não). O material manipulado foi colocado em uma moldeira de forma a cobrir totalmente sua parte interna. Posteriormente, foi colocado sobre uma matriz metálica apresentando linhas de 20, 50 e $75 \mu \mathrm{m}$. Os moldes foram removidos após a polimerização e a reprodução de detalhes da superfície 
foi mensurada em um microscópio comparador (Microscópio Stereozoom), ao longo da linha de $20 \mu \mathrm{m}$ ( $25 \mathrm{~mm}$ de comprimento), com ampliação de 4x, em conformidade com a ISO 4823. Os valores de reprodução de detalhes da superfície foram submetidos a uma análise descritiva - os resultados foram expressos em porcentagem (\%). Todos os grupos apresentaram $100 \%$ de reprodução de detalhes da superfície, independente do material de impressão ou prazo de validade. A reprodução de detalhes da superfície dos materiais investigados não foi influenciada pela data de validade dos elastômeros avaliados.

Palavras-chave: Elastômeros; Materiais para moldagem odontológica; Prazo de validade de produtos.

\section{Resumen}

Los elastómeros son materiales de caucho sintético formados por polímeros, unidos por un pequeño número de enlaces cruzados que forman una red tridimensional. El objetivo del presente estudio fue comparar la reproducción de detalles de la superficie de los materiales de impresión elastoméricos a base de silicona de adición y poliéter (2 años después de la fecha de caducidad) con aquellos que no excedieron su fecha de caducidad. Se dividieron cuatro grupos que constaban de 5 muestras cada uno $(n=5)$ según el material (silicona de adición - Express y poliéter Impregum Soft) y el plazo de caducidad (vencida o no). El material manipulado fue colocado en una cubeta de forma a cubrir totalmente la parte interna. Posteriormente, se colocó sobre una matriz metálica con líneas de 20, 50 y 75 $\mu \mathrm{m}$. Los moldes se retiraron después de la polimerización y la reproducción de detalles de la superficie se midió en un microscopio comparador (Microscópio Stereozoom), a lo largo de la línea $20 \mu \mathrm{m}$ (25 mm de largo), con aumento $4 \mathrm{x}$, en conformidad con el ISO 4823. Los valores de reproducción de detalle de la superficie fueron sometidos a análisis descriptivo, los valores fueron expresados en porcentajes (\%). Todos los grupos mostraron $100 \%$ de reproducción de detalle de la superficie, independiente del material de impresión o de la fecha de caducidad. La reproducción de los detalles de superficie de los materiales investigados no se vio influenciada por la fecha de caducidad de los elastómeros evaluados.

Palabras clave: Elastómeros; Materiales de impresión dental; Fecha de caducidad de productos.

\section{Introduction}

Elastomers are synthetic rubber materials formed by polymers, which are joined by a small number of cross-links that form a three-dimensional network. Nowadays, four elastomer types (polysulfide, polydimethylsiloxane, polyvinyl siloxane and polyether) have been used in the dentistry field (Guiraldo et al., 2017). Polyvinyl siloxane is a naturally-hydrophobic impression material given the siloxane cross-links surrounded by aliphatic hydrocarbons (Aivatzidou et al., 2020); however, surfactants' (oligoethers) addition to it, turns it into a hydrophilic material. On the other hand, the inherently hydrophilic nature of polyether materials is due to the exposed oxygen atoms of the ethylene oxide, which are parts of the tetrahydrofuran copolymer (Menees et al., 2015). Overall, hydrophilic materials show better impression surface and generate casts without pores. Polyether and polyvinyl siloxane impression materials are indicated due to their high surface detail reproduction property, among others.

The impression material accuracy associated with dimensional stability, as well as its compatibility to gypsum stuff, are essential preconditions for successful restorations. Accurate surface detail reproduction of prepared teeth or edentulous arches play critical role in the manufacture of fixed and removable protheses. Inaccuracies in replication processes have negative effects on the adjustment and adaptation of final restorations (Chong et al., 1990). Elastomers are known for their high accuracy among impression materials available in the market (Petrie et al., 2003); polyether and polyvinyl siloxane are the elastomers most used in dental prosthesis (Johnson et al., 2010). Elastomers can lose their features after the expiration date. Guiraldo et al. (2020) have evaluated the dimensional stability of elastomers that have exceeded the expiration date, but they suggested the conduction of further studies to assess different properties of this material. Therefore, the aim of the current study was to compare the surface detail reproduction of polyether and polyvinyl siloxane-based elastomeric impression materials, 2 years after their expiration date, to the ones that have not exceeded this period.

\section{Methodology}

Elastomeric-impression dental materials used in the current study comprised: polyvinyl siloxane (Express, 3M Deutschland GmbH, Seefeld, Germany) and polyether (Impregum Soft, 3M Deutschland GmbH). Elastomers were divided 
into subgroups based on their expiration date: one group comprised materials that exceeded the expiration date by 2 years and one group comprising materials that have not exceeded this period; in total, 4 groups comprising 5 samples, each ( $\mathrm{n}=5$ ), were formed. Detail reproduction focused on obtaining elastomeric impression was determined by following ISO 4823:2000 standard specifications. Thus, impression procedures were carried out over standard metallic matrix, by using the following references lines: three horizontal lines measuring $20 \mu \mathrm{m}, 50 \mu \mathrm{m}$ and $75 \mu \mathrm{m}$ (in depth) and two vertical lines (at the opposite ends) measuring $25 \mathrm{~mm}$ (in length). Before performing the impression procedure, the matrix was ultrasonically cleaned and dried with compressed air.

Standard trays were used in impression procedures. Elastomers were hand-mixed by following manufacturer's instructions, under controlled temperature and relative humidity conditions $\left(23^{\circ} \mathrm{C} \pm 2{ }^{\circ} \mathrm{C}\right.$ and $\left.50 \% \pm 10 \%\right)$. After the materialhandling process was over, it was placed on the tray (31 mm internal diameter $\times 5 \mathrm{~mm}$ high) and subsequently placed on metallic matrix. The tray was joined to the matrix and a pressure of $2 \mathrm{kgf}$ was applied using a pneumatic press to simulate the impression process and permit leakage of excess material (Carvalhal et al., 2011). Detail reproduction was measured in the impression, along the $20-\mu \mathrm{m}$ line $(25 \mathrm{~mm}$, in length), in optical microscope (Stereozoom Microscope, Bel Engineering Srl, Monza, Italy), at 4x-magnification. All readings have followed the same environmental, temperature and humidity conditions in order to avoid the influence of external factors on the analysis and to ensure trustworthy results. Surface detail reproduction values were subjected to descriptive analysis - results were expressed in percentage (\%) - in compliance with ISO 4823:2000 specifications.

\section{Results}

Based on the current results (Table 1), all groups presented $100 \%$ of surface detail reproduction, regardless of material or expiration date.

Table 1 - Surface detail reproduction in the different groups investigated in the current study.

\begin{tabular}{ccc} 
& \multicolumn{3}{c}{ Surface Detail Reproduction (\%) } \\
\cline { 2 - 3 } Elastomer & Non-expiration & 2 years after the expiration date \\
\cline { 2 - 3 } Polyvinyl Siloxane & 100 & 100 \\
Polyether & 100 & 100 \\
\hline
\end{tabular}

Source: Authors.

\section{Discussion}

Surface detail reproduction of impressions is essential for the overall success of prosthodontic treatments. Ideally, impression materials should present stable dimension over time to allow operators to pour the impression at convenience. Surface detail reproduction of dental impression materials is of utmost importance to achieve the desired fit and function of future prostheses. Different methods have been used in previous studies to measure dimensional changes; among them, one finds Boley's gauge, measuring microscope, traveling microscope, digimatic caliper, toolmaker's microscope, Nikon profile projector and 2D computer scanner (Amin et al., 2009; Kamegawa et al., 2010). Several studies have assessed the dimensional changes by either measuring on full arch cast or in metal die manufactured in compliance with American Dental Association (ADA) Specification n. 19 (Abdelaziz et al., 2004; Melilli et al., 2008; Amin et al., 2009). Other studies have also directly 
evaluated it on impressions (Guiraldo et al., 2017; Guiraldo et al., 2018). Thus, the current study has evaluated the surface detail reproduction in impressions, in compliance with ISO 4823:2000 Specification.

Clinical success of impression materials depends on their acceptable physical and mechanical properties. The viscoelastic properties of elastomeric impression materials play important role in their successful application as high-precision impression materials. The amount of permanent deformation assigned to the instrumental panel is defined based on strain duration or on compression running into the material (Pandey et al., 2019). Random deformation by 0.4\% was the limit to clinical significance (Craig, 1988). This deformation depends on the depth of the surface detail, which is one of the most important properties for proper assessments of impression materials to be used for clinical purposes. Thus, the current study has evaluated the surface detail reproduction of polyvinyl siloxane (Express) and polyether (Impregnum Soft) materials (20 $\mu \mathrm{m}$, in depth; and $25 \mathrm{~mm}$, in length), within the expiration date and 2 years after it.

Qualities attributed to these materials comprised excellent detail reproduction, dimensional stability, elastic recovery and tear energy (German et al., 2008; Aivatzidou et al., 2020). In addition, modern elastomeric impression materials exhibit superior handling characteristics, dimensional stability after disinfection and for prolonged periods, as well as wettability from dental stone mix (Gonçalves et al., 2011). However, these materials are too expensive in comparison to other materials and their expiration date should be extended to enable better using them. Guiraldo et al. (2020) have found similar dimensional stability among these materials, either within the expiration date or 2 years after it, but they did not assess detail reproduction. Polyvinyl siloxane and polyether investigated in the current study reproduced $100 \%$ of details both within the expiration date and 2 years after it. However, other properties should be assessed in future studies in order to test materials with longer expiration date. According to SESA n. 496/2005, which regulates technical standards, as well as the installation and operation of dental care offices and accommodations (Chapter XV), dentists account for monitoring the expiration date of dental materials used in all procedures. Non-compliance with this resolution is a violation that leads to penalties (Guiraldo et al., 2020). The aim of the current study was not to validate the expiration date of products, but to investigate elastomers' rheology in order to contribute to future expansions in the expiration date of these important dental materials.

\section{Conclusion}

Based on the herein adopted conditions, and despite the limitations of the current study, it was possible concluding that the detail reproduction was not affected by the 2-year time lapse after the expiration date set for polyvinyl siloxane and polyether impression materials.

\section{References}

Abdelaziz, K. M., Attia, A., \& Combe, E. C. (2004). Evaluation of disinfected casts poured in gypsum with gum Arabic and calcium hydroxide additives. The Journal of Prosthetic Dentistry, 92(1), 27-34.

Aivatzidou, K., Kamalakidis, S. N., Emmanouil, I., Michalakis, K., \& Pissiotis, A. L. (2021). Comparative Study of Dimensional Stability and Detail Reproduction of Reformulated and Nonreformulated Elastomeric Impression Materials. Journal of Prosthodontics, 30(4), 345-350.

Amin, W. M., Al-Ali, M. H., Al Tarawneh, S. K., Taha, S. T., Saleh, M. W., \& Ereifij, N. (2009). The effects of disinfectants on dimensional accuracy and surface quality of impression materials and gypsum casts. Journal of Clinical Medicine Research, 1(2), 81-89.

Chong, Y. H., Soh, G., Setchell, D. J., \& Wickens, J. L. (1990). The relationship between contact angles of die stone on elastomeric impression materials and voids in stone casts. Dental Materials, 6(3), 162-166.

Carvalhal, C. I., Mello, J. A., Sobrinho, L. C., Correr, A. B., \& Sinhoreti, M. A. (2011) Dimensional change of elastomeric materials after immersion in disinfectant solutions for different times. The Journal of Contemporary Dental Practice, 12(4), 252-258.

Craig, R. G. (1988). Review of dental impression materials. Advances in Dental Research, 2(1), 51-64.

German, M. J., Carrick, T. E., \& McCabe, J. F. (2008). Surface detail reproduction of elastomeric impression materials related to rheological properties. Dental Materials, 24(7), 951-956. 
Gonçalves, F. S., Popoff, D. A. V., Castro, C. D. L., Silva, G. C., Magalhães, C. S., \& Moreira, A. N. (2011). Dimensional stability of elastomeric impression materials: a critical review of the literature. European Journal of Prosthodontics and Restorative Dentistry, 19(4), $163-166$.

Guiraldo, R. D., Berger, S. B., Siqueira, R. M., Grandi, V. H., Lopes, M. B., Gonini-Júnior, A., Caixeta, R. V., de Carvalho, R. V., \& Sinhoreti, M. A. (2017). Surface detail reproduction and dimensional accuracy of molds: influence of disinfectant solutions and elastomeric impression materials. Acta Odontologica Latinoamericana, 30(1), 13-18.

Guiraldo, R. D., Berger, S. B., Punhagui, M. F., Moretto, T. S., Lopes, M. B., Gonini-Júnior, A., \& Sinhoreti, M. A. C. (2018). Influence of chloramine-T disinfection on elastomeric impression stability. European Journal of Dentistry, 12(02), 232-236.

Guiraldo, R. D., Berger, S. B., Paloco, E. A. C., dos Reis Freitas, A., Lopes, M. B., de Carvalho, R. R., Seixas, G. F., \& Sinhoreti, M. A. C. (2020). Influence of expiration date on the dimensional accuracy of elastomers. Research, Society and Development, 9(10), e489108147.

Haralur, S. B., Saad Toman, M., Ali Al-Shahrani, A., \& Ali Al-Qarni, A. (2016). Accuracy of multiple pour cast from various elastomer impression methods. International Journal of Dentistry, 2016:7414737.

Johnson, G. H., Mancl, L. A., Schwedhelm, E. R., Verhoef, D. R., \& Lepe, X. (2010). Clinical trial investigating success rates for polyether and vinyl polysiloxane impressions made with full-arch and dual-arch plastic trays. The Journal of Prosthetic Dentistry, 103(1), 13-22.

Kamegawa, M., Nakamura, M., Fukui, Y., Tsutsumi, S., \& Hojo, M. (2010). Direct 3-D morphological measurements of silicone rubber impression using micro-focus X-ray CT. Dental Materials Journal, 29(1), 68-74.

Khatri, M., Mantri, S. S., Deogade, S. C., Bhasin, A., Mantri, S., Khatri, N., Jain, P., \& Chauhan, D. (2020). Effect of chemical disinfection on surface detail reproduction and dimensional stability of a new vinyl polyether silicone elastomeric impression material. Contemporary Clinical Dentistry, 11(1), 10-14.

Melilli, D., Rallo, A., Cassaro, A., \& Pizzo, G. (2008) The effect of immersion disinfection procedures on dimensional stability of two elastomeric impression materials. Journal of Oral Science, 50(4), 441-446.

Menees, T. S., Radhakrishnan, R., Ramp, L. C., Burgess, J. O., \& Lawson, N. C. (2015). Contact angle of unset elastomeric impression materials. The Journal of Prosthetic Dentistry, 114(4), 536-542.

Pandey, P., Mantri, S., Bhasin, A., \& Deogade, S. C. (2019). Mechanical properties of a new vinyl polyether silicone in comparison to vinyl polysiloxane and polyether elastomeric impression materials. Contemporary Clinical Dentistry, 10(2), 203-207.

Petrie, C. S., Walker, M. P., O'mahony, A. M., \& Spencer, P. (2003). Dimensional accuracy and surface detail reproduction of two hydrophilic vinyl polysiloxane impression materials tested under dry, moist, and wet conditions. The Journal of Prosthetic Dentistry, 90(4), 365-372.

Soganci, G., Cinar, D., Caglar, A., \& Yagiz, A. (2018). 3D evaluation of the effect of disinfectants on dimensional accuracy and stability of two elastomeric impression materials. Dental Materials Journal, 37(4), 675-684. 